\title{
Apparent Nutrient Digestibility of Plant Based Diets by Tilapia rendalli (Boulenger, 1896)
}

\author{
Mzengereza $\mathbf{K}^{1 *}$, Singini $\mathbf{W}^{1}$, Msiska OV${ }^{1}$, Kapute $\mathrm{F}^{1}$, Kang'ombe $\mathrm{J}^{\mathbf{2}}$ and Kamangira $\mathrm{A}^{1}$
}

${ }^{1}$ Department of Fisheries Science, Mzuzu University, Private Bag 201, Mzuzu 2, Malawi

${ }^{2}$ Department of Aquaculture and Fisheries Science, Lilongwe University of Agriculture and Natural Resources, Bunda College, P.O. Box 219, Lilongwe, Malawi

\begin{abstract}
This study investigated the digestibility of diets formulated exclusively out of plant sources fed to Tilapia rendalli. The study was conducted at NkhataBay Fisheries Laboratory along Lake Malawi for 21 days. The experiment was laid out in a Completely Randomized Design (CRD) using $30 \times 30 \times 35 \mathrm{~cm}$ glass aquaria with each of the four experimental isonitrogeous diets containing varying plant sources replicated three times. Juvenile Tilapia rendalli $(25.0 \pm 1.0 \mathrm{~g})$ were conditioned for 5 days to accept the artificial dry plant feed fed two times a day. Faeces were collected by stripping method using a tube and pipette, preserved in beakers and later analyzed for chemical composition. An indirect method of measuring digestibility was used to calculate the apparent digestibility coefficients (ADCs) of the diets containing $1 \%$ Chromic oxide and faeces. Water quality data was measured on daily basis using a spectrophotometer. Data was analyzed using Analysis of variance (ANOVA) at $P=0.05$ using R- statistical software. Protein digestibility coefficient ranged from $30.82 \% \pm 0.81$ to $29.21 \% \pm 0.91$. However, apparent digestibility coefficients for gross energy were slightly higher than those of other elements. Results show that nutritional and digestibility value provide a good support for the development of a system of selecting ingredients for inclusion in fish diets.
\end{abstract}

Keywords: Tilapia rendalli; Plant diets; Digestibility; Feaces; Gross energy; Crude protein

\section{Introduction}

Tilapia has been identified as one of the species with greatest potential to contribute to fish production in Malawii. Previously, Tilapia was consumed mainly in Africa and Asia but nowadays it has been touted as the "new white fish" replacing the depleted ocean stocks, leading to a worldwide demand for the fish. Globally, fish feeds usually contain high levels of dietary protein, supplied especially by fish meal, the main protein source for aqua feed Deng et al. Wu et al. Glencross et al. $[1,2]$. However, there are many risks associated with availability, price and quality fluctuations of fish meal in the international market. Therefore, In order to enhance aquaculture production, improve food security and reduce the level of poverty in developing countries, a search for cheap and locally available feedstuffs is required Munguti et al.

In Malawi, Tilapia rendalli can play an important role under extensive/semi-intensive fish pond culture system as it feeds mainly on readily available macrophytes. Tilapia rendalli is a promising alternative candidate because of its ability to utilize plant protein which is relatively cheap compared to the conventional fishmeal. According to El-Sayed, Tilapia rendalli exhibits desirable attributes including: feeding at low trophic levels (feed largely conditions such as temperature, low dissolved oxygen levels, high ammonia levels, it has a fairly fast growth rate and ability to reproduce readily in captivity and does not incubate eggs in the mouth.

Sustainability of aquaculture will depend on the replacement of fish meal by alternative protein sources in aqua feeds [2-4]. However, finding alternative plant protein sources in aquaculture feeds is a challenging task. Plant proteins have limitations that impede its potential. Fibres are indigestible and nutritionally unavailable carbohydrates in animal and plant sources and are usually used as fillers and binders in fish feeds. Fish can tolerate up to a certain amount of dietary fiber which is generally $>10 \%$ before it start affect growth rate. Presence of Anti nutritional factors that are deletelous to health of fish and also low amino acid and protein are other potential hazards of plant proteins.

The nutritional value of a given feedstuff is based not only in its chemical composition, but also in its nutrients and energy availability. Availability of nutrients for fish should be defined mainly items of their digestibility, that is, the fraction of nutrients from the ingested feed and feed ingredients that will not be excreted in the faeces. Digestibility determination is one of the nutritional assessment tools that must be employed to deduce the availability of nutrients levels in the plant diets that can be turned into fresh. Determination of digestibility is the first step in evaluating the potential of an ingredient for use in the diet of an aquaculture species [1]. Nutritive value of feeds is determined by a number of factors, including composition, odor, texture and taste. The apparent digestibility of nutrients like protein, energy and individual amino acids are of prime consideration as the basis for feed formulation and for experimental purposes in fish in the path of results of Portz and Cyrino [4], this study aims at evaluating the digestibility of exclusively formulated plant protein based diets by a model herbivorous fish, the Tilapia rendalli. The information gained will be utilized in the feed manufacturing industry to foster the use of alternative, plant proteins $s$ in diets for intensive production of Tilapia.

*Corresponding author: Mzengereza K, Department of Fisheries Science, Mzuzu University, Private Bag 201, Mzuzu 2, Malawi, Tel: +265 88899 8466; E-mail: kumbumzenge@yahoo.com

Received October 17, 2015; Accepted October 30, 2015; Published January 15 2016

Citation: Mzengereza K, Singini W, Msiska OV, Kapute F, Kang'ombe J, et al (2016) Apparent Nutrient Digestibility of Plant Based Diets by Tilapia rendall (Boulenger, 1896). J Aquac Res Development 7: 396 . doi:10.4172/21559546.1000396

Copyright: (c) 2016 Mzengereza K, et al. This is an open-access article distributed under the terms of the Creative Commons Attribution License, which permits unrestricted use, distribution, and reproduction in any medium, provided the original author and source are credited. 


\section{Materials and Methods}

\section{Collection of locally available plant ingredients}

An observational survey by farmers and researchers was conducted in Mpamba; NkhataBay northern Malawi to identify locally available plants for assessment of their nutritional profile. The aim was to ascertain the plant's potential for inclusion into diets for pond raised fish (tilapias species). Selection of the feedstuffs was based on both temporal and spatial availability, abundance; competition for other uses, prior nutritional profile from literature and cost implication. The following plant ingredients were collected: Cassava (Manihot esculenta) peels and leaves, Pawpaw (Carica papaya) leaves, Sweet potato (Ipomea batatus) leaves, meal and tubers, Jackfruit (Artocarpus heterophyllus), Mexican fireplant (Euphorbia heterophylla), Black jack (Bidens pilosa), Cocoyam (Colocasia esculenta) leaves, Banana (Musa balbisiana) leaves, Maize (Zea mais) bran, and Akee (Blighia sapid) leaves.

\section{Processing of plant ingredients}

All plant ingredients were dried in the sun for three days to reduce their toxicity [5]. Drying of ingredients was done not only to reduce toxicity but also to mill them into powder form ready for proximate analysis. Ingredients were milled using a mortar and pestle. Finally, the ingredients were then sieved using a wooden sieve to remove cellulose and lignin materials to remain with the powder.

\section{Proximate analysis of plant feedstuffs}

Proximate analysis of the plant ingredients was done at Department of Aquaculture and Fisheries Science laboratory Lilongwe University of Agriculture and Natural Resources (LUANAR), Bunda College Campus, The plant samples were analyzed for crude protein, crude fiber, crude fat, ash and moisture content done in triplicate, following the procedure outlined by the Association of Official Analytical Chemists AOAC [6].

\section{Fish and experimental condition}

This study was conducted at the Department of Fisheries Science Laboratory, Mzuzu University located in NkhataBay, northern Malawi. Each treatment had three replicates, 10 Tilapia rendalli per replicate, with mean initial fish weights of $25 \pm 2 \mathrm{~g}$. Each treatment was randomly assigned to three glass aquaria (measurement in $\mathrm{L}$ ). Which were supplied with freshwater from Lake Malawi that had average temperature $21 \pm 2^{\circ} \mathrm{C}$, dissolved oxygen $7.3 \pm 0.3 \mathrm{mg} \mathrm{L} \_1$ and $\mathrm{pH} 7.1 \pm$ 0.2 . Fish were exposed to natural daily light regime.

\section{Feed ingredient and diet preparation}

Locally available plant ingredients obtained from Mpamba NkhataBay were evaluated for proximate composition (Table 1). The ingredients were Cassava leaf and flour, sweet potato leaf and meal, Black jack and Cocoyam leaf. The fresh plant sources were dried in the sun for three days to remove anti-nutritional factors as recommended by Francis et al. [3] before being milled using a traditional mortar and pestle. The experimental diets were formulated using the trial and error method. Chromic oxide $\left(\mathrm{Cr}_{2} \mathrm{O}_{3}\right)$ was used as an inert marker in reference diet (Table 2). Each test ingredient was ground and sieved to produce powder. Diets were mechanically mixed with warm water to make dough which was later used to produce pellets. The resultant moist pellets were then dried at under a shade for approximately $12 \mathrm{~h}$. After that, the feeds were then broken up and sieved into convenient pellet sizes $(2-3 \mathrm{~mm})$ and were stored in polythene bags at $4^{\circ} \mathrm{C}$. The amount of diet needed weekly was then kept at room temperature [7].

\section{Experimental procedure}

During acclimatization period, fish were fed with experimental diets for 7 days prior to the beginning of fecal collection. All fish were fed two times at 09:00am and 2:00pm respectively at the rate of $4 \%$ of their body weight on a daily basis during 21 days. On termination of the experiment, fish were weighed individually and mean weight for each aquarium was calculated. One hour after the feed was administered; any feed and feces present in the aquaria were removed.

\section{Feacal collection}

Faecal matter was collected from the aquaria by using a siphon and a pipette into a petri dish. Feacal collection was done within 2 hours of voiding during the day and the fecal material voided during the night was collected next morning at 07:00 hours. Feacal collection was done for 21 days. Samples from two replicates in each treatment replicated twice were pooled and kept in beakers to dry until analysis. Prior to the analysis, samples from the rest of the days from fish on each experimental diet were pooled together and analyzed.

\section{Biochemical analysis of fecal and feed material}

The fecal and feed material for the entire experimental period were pooled in triplicates samples and then analyzed for Crude protein, Ether extract (fat), fiber, and ash, following the procedures stipulated by the Association of Official Analytical Chemists [6] while gross energy was analyzed using a bomb calorimeter and chromic oxide was determined according to Fenton \& Fenton. Total nitrogen (N) was determined by the Kjeldahl method and CP content was calculated as $\mathrm{N} \times 6.25$. Ether extract was determined by Soxhlet extraction without acid hydrolysis. Ash was the residue after ashing the samples at 550$600^{\circ} \mathrm{C}$. Fiber content determined using acid-base digestion according to Robertson and Van Soest.

\section{Digestibility determination}

Apparent digestibility coefficients (ADCs) of each nutrient in the

\begin{tabular}{|l|c|c|c|}
\hline Ingredients & Diet 1 (18\%) CP & Diet 2 (18\%)CP & Diet 3 (18)CP \\
\hline Cassava leaf meal (kg) & 31.4 & 31.4 & 23.4 \\
\hline Cocoyam meal(kg) & - & 31.4 & 19.4 \\
\hline Black jack(Kg) & 31.4 & - & 19.4 \\
\hline \multicolumn{1}{|c|}{ Maize bran (kg) } & 11.4 & 11.4 & - \\
\hline Sweet potato meal(Kg) & 11.4 & 11.4 & 19.4 \\
\hline Sweet potato leaf meal(Kg) & 11.4 & 11.4 & 17.4 \\
\hline Cassava Flour & 2 & 2 & 17.4 \\
\hline Chromic oxide & 1 & 1 & 2 \\
\hline Total & 100 & 100 & 1 \\
\hline
\end{tabular}

Table 1: Percentage ingredient composition of the experimental diets fed to Tilapia rendalli. 
Citation: Mzengereza K, Singini W, Msiska OV, Kapute F, Kang'ombe J, et al. (2016) Apparent Nutrient Digestibility of Plant Based Diets by Tilapia rendalli (Boulenger, 1896). J Aquac Res Development 7: 396. doi:10.4172/2155-9546.1000396

Page 3 of 6

\begin{tabular}{|c|c|c|c|c|c|c|}
\hline $\begin{array}{l}\text { Ingredient } \\
\text { Analyzed }\end{array}$ & Moisture & Ash & Fiber & Protein & Fat & $\begin{array}{c}\text { Energy } \\
\mathrm{Kj} / \mathrm{g}\end{array}$ \\
\hline CL & $11.97 \pm 0.75^{a}$ & $13.6 \pm 0.65^{b}$ & $16.35 \pm 0.75^{a}$ & $21.17 \pm 0.56^{a}$ & $3.16 \pm 0.00^{b}$ & 20.59 \\
\hline SPL & $10.89 \pm 0.31^{a}$ & $85.75 \pm 0.0^{\mathrm{a}}$ & $9.16 \pm 0.70^{c}$ & $8.40 \pm 0.10^{c}$ & $2.98 \pm 0.25^{b}$ & 29.7 \\
\hline CYL & $7.08 \pm 1.56^{a}$ & $14.84 \pm 0.45^{b}$ & $3.95 \pm 0.15^{b}$ & $24.28 \pm 0.11^{d}$ & $7.23 \pm 1.52^{c}$ & 19.54 \\
\hline BJ & $20.79 \pm 0.71^{d}$ & $23.1 \pm 0.91^{c}$ & $6.40 \pm 0.75^{b}$ & $24.35 \pm 0.7^{d}$ & $5.65 \pm 0.93^{b}$ & 12.4 \\
\hline MZB & $8.87 \pm 0.90^{\mathrm{a}}$ & $3.72 \pm 0.32^{b}$ & $3.40 \pm 0.15^{b}$ & $11.81 \pm 0.11^{c}$ & $7.28 \pm 1.90^{c}$ & 15.72 \\
\hline SPM & $9.67 \pm 0.11^{\mathrm{a}}$ & $85.7 \pm 0.15^{a}$ & $3.19 \pm 0.30^{b}$ & $11.97 \pm 0.45^{c}$ & $3.2 \pm 0.45^{b}$ & 15.32 \\
\hline
\end{tabular}

Values (Mean \pm SE) in a column with different superscript letters are significantly different $(P<0.05)$; Where; CL: Cassava Leaf, CP: SML: Sweet Potato Meal, CYL: Cocoa yam, BJ: Black Jack, MZB: Maize Bran, SPM: Sweet potato meal.

Table 2: Proximate composition of plant ingredients from Mpamba (Mean \pm SE) expressed as percent (\%) dry matter

\begin{tabular}{|c|c|c|c|c|c|c|}
\hline Element Analyzed & Crude protein & Energy Kg/j & Fat & Fibre & Ash & Moisture (DM) \\
\hline Treatment 1 & $61.88 \pm 0.25^{a}$ & $15.25 \pm 0.05^{\mathrm{a}}$ & $24.04 \pm 0.14^{\mathrm{a}}$ & $0.32 \pm 0.006^{a}$ & $0.33 \pm 0.03^{a}$ & $36.78 \pm 0.03^{a}$ \\
\hline Treatment 2 & $63.21 \pm 0.03^{\mathrm{ab}}$ & $14.69 \pm 0.02^{\mathrm{b}}$ & $22.69 \pm 0.10^{\mathrm{a}}$ & $0.37 \pm 0.006^{b}$ & $0.35 \pm 0.08^{b}$ & $34.91 \pm 0.03^{b}$ \\
\hline Treatment 3 & $62.71 \pm 0.07^{\mathrm{ab}}$ & $15.78 \pm 0.06^{c}$ & $27.2 \pm 0.28^{b}$ & $0.38 \pm 0.00^{\mathrm{b}}$ & $0.34 \pm 0.03^{c}$ & $34.76 \pm 0.03^{b}$ \\
\hline Treatment 4 & $62.38 \pm 0.03^{b}$ & $15.36 \pm 0.04^{a}$ & $26.64 \pm 0.08^{b}$ & $0.36 \pm 0.003^{\mathrm{ab}}$ & $0.34 \pm 0.03^{c}$ & $32.43 \pm 0.03^{a}$ \\
\hline
\end{tabular}

Values (Mean $\pm \mathrm{SE}$ ) in a column with different superscript letters are significantly different $(\mathrm{P}<0.05)$.

Table 3: Proximate composition (\%) of the whole body carcass of Tilapia rendalli fed on pelleted diets containing different plant feedstuffs.

\begin{tabular}{|c|c|c|c|c|c|c|}
\hline Element Analyzed & Crude protein & Energy Kg/j & Fat & Fibre & Ash & Moisture (DM) \\
\hline Diet 1 & $29.52 \pm 0.07^{a}$ & $10.99 \pm 0.09^{a}$ & $9.57 \pm 0.12^{\mathrm{a}}$ & $4.28 \pm 0.04^{a}$ & $14.76 \pm 0.05^{\mathrm{ab}}$ & $92.52 \pm 0.06^{a}$ \\
\hline Diet 2 & $30.5 \pm 0.05^{\mathrm{b}}$ & $10.81 \pm 0.09^{b}$ & $10.95 \pm 0.05^{b}$ & $4.31 \pm 0.09^{a}$ & $14.3 \pm 0.05^{\mathrm{ab}}$ & $93.14 \pm 0.02^{b}$ \\
\hline Diet 3 & $29.31 \pm 0.19^{a}$ & $11.18 \pm 0.02^{a}$ & $11.5 \pm 0.06^{c}$ & $4.02 \pm 0.07^{b}$ & $14.1 \pm 0.03^{b}$ & $92.64 \pm 0.04^{a}$ \\
\hline Diet 4 & $30.82 \pm 0.81^{c}$ & $10.38 \pm 0.02^{c}$ & $9.5 \pm 0.11^{c}$ & $4.49 \pm 0.02^{c}$ & $15.06 \pm 0.01^{a}$ & $93.55 \pm 0.34^{c}$ \\
\hline
\end{tabular}

Values (Mean $\pm S E$ ) in a column with different superscript letters are significantly different $(P<0.05)$.

Table 4: Proximate composition (\%) of feed containing different plant feedstuffs fed to Tilapia rendalli.

\begin{tabular}{|l|c|c|c|c|}
\hline Element Analyzed & Crude protein & Energy Kg/j & Fat & Ash \\
\hline Diet 1 & $30.44 \pm 0.29^{\mathrm{a}}$ & $43.44 \pm 0.59^{\mathrm{a}}$ & $67.78 \pm 1.35^{\mathrm{a}}$ & $23.77 \pm 0.95^{\mathrm{a}}$ \\
\hline Diet 2 & $31.45 \pm 0.34^{\mathrm{b}}$ & $31.50 \pm 0.36^{\mathrm{b}}$ & $61.54 \pm 0.91^{\mathrm{b}}$ & $3.82 \pm 0.66^{\mathrm{a}}$ \\
\hline Diet 3 & $30.04 \pm 0.06^{\mathrm{a}}$ & $31.04 \pm 0.34^{\mathrm{b}}$ & $61.65 \pm 0.71^{\mathrm{b}}$ & $4.34 \pm 1.35^{\mathrm{a}}$ \\
\hline Diet 4 & $24.15 \pm 0.28^{\mathrm{c}}$ & $21.56 \pm 0.34^{\mathrm{c}}$ & $54.29 \pm 2.22^{\mathrm{c}}$ & $26.93 \pm 0.76^{\mathrm{c}}$ \\
\hline
\end{tabular}

Values (Mean $\pm S E)$ in a column with different superscript letters are significantly different $(P<0.05)$.

Table 5: Apparent digestibility coefficients (\%) of plant diet fed to Tilapia rendalli (DM).

test diet $\left(\mathrm{ADCN}_{\text {diet }}\right)$ were calculated according to $\mathrm{t}$

$$
A D C N_{d t}=100-\left\{100\left[\left(C r_{d} / C r_{f}\right) x\left(F_{n} / D_{n}\right)\right]\right\}
$$

Where:

$\mathrm{ADCN}_{d t}=$ Apparent Digestibility Coeffient of Nutrients in the diets

$\mathrm{Cr}_{d} \quad=\%$ Chromic Oxide in the diet

$\mathrm{Cr}_{f} \quad=\%$ Chromic Oxide in the feaces

$F_{\mathrm{n}} \quad=\%$ nutrient in feaces

$D_{n} \quad=\%$ nutrient in feaces

\section{Data analysis}

Apparent digestibility coefficients for protein, fat, fiber, ash and energy were subjected to a one-way analysis of variance within each collection method using the R statistical software. Diet was considered the fixed effect, whereas replicate tank within diet was considered the random effect. Differences in ADCs among diets were determined according to Duncan's multiple range test mean comparison Duncan, [8] and were considered significant at $\mathrm{P}<005$.

\section{Results}

\section{Apparent digestibility coefficients (ADCs)}

The apparent digestibility coefficients determined by indirect method of digestibility as reported in Table 3.

\section{Protein digestibility}

The protein digestibility coefficient ranged from $31.45 \%$ to $24.15 \%$. There were significant differences among the digestibility of protein in different diets $\mathrm{P}(<0.05)$. But Protein digestibility between diets 1 and 3 was not significantly different $\mathrm{P}(>0.05)$. However, diet $2(31.45 \%)$ had the highest digestibility coefficient, followed by diet 1 (30.44\%), then diet $3(30.04 \%)$ and lastly diet 4 (24.15\%) (Tables 4 and 5).

\section{Fat digestibility}

The fat digestibility coefficient ranged from $67.78 \%$ to $54.29 \%$. There were significant differences among the digestibility of fat in different diets $\mathrm{P}(<0.05)$. But fat digestibility between diets 2 and was not significantly different $\mathrm{P}(>0.05)$. However, diet 1 (67.78\%) had the highest digestibility coefficient, followed by diet 3 (61.65\%), then diet 2 (61.54\%) and lastly diet 4 (54.29\%) (Table 5). 


\section{Ash digestibility}

The fat digestibility coefficient ranged from $11.80 \%$ to $3.82 \%$. There were significant differences among the digestibility of ash in different diets $\mathrm{P}(<0.05)$. But ash digestibility for diets1, 2 and 3 was not significantly different $\mathrm{P}(>0.05)$ However, diet $4(11.80 \%)$ had the highest digestibility coefficient, followed by diet $3(4.82 \%)$, then diet 2 (4.34\%) and lastly diet 4 (3.82\%) (Table 5).

\section{Crude fibre digestibility}

The fat digestibility coefficient ranged from $39.57 \%$ to $23.77 \%$. There were significant differences among the digestibility of fat in different diets $\mathrm{P}(<0.05)$. But fibre digestibility between diets 1 and 4 was not significantly different $\mathrm{P}(>0.05)$. However, diet $2(39.57 \%)$ had the highest digestibility coefficient, followed by diet 3 (26.93\%), then diet 4 (24.29\%) and lastly diet 1 (23.77\%) (Table 5).

\section{Gross energy digestibility}

The gross energy digestibility coefficient ranged from $43.44 \%$ to $21.56 \%$. There were significant differences among the digestibility of energy in different diets $\mathrm{P}(<0.05)$. But gross energy digestibility between diets 2 and 3 was not significantly different $P(>0.05)$ However, diet $1(43.44 \%)$ had the highest digestibility coefficient, followed by diet $2(31.50 \%)$, then diet $3(30.04 \%)$ and lastly diet $4(21.56 \%)$ (Table 5).

\section{Discussion}

The average values of faeces composition and the diets digestibility coefficients for Tilpia rendalli are presented in Table 5. The treatment 1 presented the highest values $(43.44 \%)$ of for energy $\left(\mathrm{ADC}_{\mathrm{GE}}\right)$ and differed $(\mathrm{P}<0.05)$ from treatments $2(31.50 \%), 3(30.04 \%)$ and 4 $(21.15 \%)$. There was less variability in values of apparent digestibility of protein coefficient $\left(\mathrm{ADC}_{\mathrm{CP}}\right)$ registered for treatment $1(30.44 \%)$ which, however, did not differ $(\mathrm{P}>0.05)$ from treatments $3(30.04 \%)$ but differed significantly $(\mathrm{P}>0.05)$ with treatments $2(31.45 \%)$ and treatments 4 (24.14\%). Apparent digestibility coefficients of lipid $\left(\mathrm{ADC}_{\mathrm{F}}\right)$ also registered the same tendency that is, similar results were registered for treatment 2 and 3, respectively (61.54\%) and (61.66\%); that differed from all other treatments $(\mathrm{P}<0.05)$.

Fish use around $80 \%$ of dietary dry matter $\left(\mathrm{ADC}_{\mathrm{DM}}\right)$ which describes how efficiently the feeds or feed ingredients are digested, and how much of their nutrient contents can be made available to fish for maintenance and growth. In addition, $\left(\mathrm{ADC}_{\mathrm{DM}}\right)$ generally provides a better estimate of the quantity of indigestible materials in the feeds or feed ingredients, rather than that of the individual nutrient.

Nutritional values of proteins and protein sources vary as a function of amino acids profile and digestibility. The proportion (\%) of crude protein, CP (i.e., Nitrogen) in a feed ingredient can either originate from protein or nonprotein nitrogen. Therefore, ingredients with high CP from non-protein nitrogen will not contribute adequate amino acids in tandem with the nutritional requirements of fish. Thus, such ingredients will on the other hand, lead to increased production ammonia and other nitrogenous wastes by the fish thereby lowering productivity and water quality of production systems [9-11].

Digestibility coefficients in this study were generally in contrast and generally lower compared with other workers on plant diets. The protein digestibility values for protein-rich feed ingredients are usually in the range of $75-95 \%$. For example, protein digestibility values sunflower cakes $86-89 \%$ and wheat bran $75 \%$ [12]. This is in agreement with the findings of Fontainhas-Fernandes et al. [13] who reported defatted soybean meal $94.4 \%$, full-fat soybean meal $90 \%$ and micronized wheat $88.6 \%$. In the same vein, Mbahinzireki et al. [14] reported values that ranged from 70 to $89 \%$ in tilapia for Cottonseed meal and corn gluten meal 89\% [11], corn meal 83-84\% [15] and Cottonseed meal 81.8\% [16] for Nile tilapia, Oreochromis niloticus.

Water quality parameters have a profound effect on the performance of fish in aquaculture and may affect feed intake as well as digestion. In the present study, water temperature records ranged from $21-22^{\circ} \mathrm{C}$ which is absolutely low as the optimum temperature range for Tilapia is $20-30 \mathrm{C}$ with better results obtained at between $26-30^{\circ} \mathrm{C}$ [9]. Thus, the temperatures recorded may have contributed to low protein digestibility as the metabolic demand was also low.

Earlier studies have shown that Tilapias have the capacity to utilize large number of alternative plant and animal protein sources [17]. Tilapia has a digestive tract that is relatively long, as in herbivorous fish, and shows morphological and physiological adaptations for the utilization of diets high in fibre $[12,18]$. This is consistent with previous work that has shown that Tilapias are capable of digesting and absorbing relative large amounts of carbohydrates [18]. Although Tilapias have an adaptation to digest plants diet, composition of nutrients of the diet influences digestibility. The source of the ingredients making up a diet can either be animal or plant based and has an effect on digestibility due to varying nutrient make up. Most plant based sources have high fibre contents especially the leafy parts unlike the animal sources. In the present study, the diets were exclusively made from plant sources and these may be responsible for low protein digestibility coefficients. Dietary plant ingredients can affect gastrointestinal transit time of feed as a result of the presence of fibres and sugars, and alter the digestibility of nutrients ingested by the fish (Storebakken et al.) [2,19]. According to Eusebio et al. [19], as dietary fibre is part of the carbohydrate component of plant ingredients, most fish cannot utilize it. However, low dietary concentrations of dietary fibre (3-5\%) may have a beneficial effect on fish growth. On the other hand, high dietary fibre $(>8 \%)$, may decrease dry matter digestibility of the diet and reduce the availability of other nutrients [20]. High dietary carbohydrate contents reduce the activity of proteolitic enzyme in fish. In the present study the fibre digestibility coefficient ranged from $23.7 \%-39.57 \%$ and therefore liable enough to impede digestibility of the diet and lock the bioavailability of other nutrients like protein.

Dietary energy is the second most important factor affecting the utilization of feeds by fish after protein. Fish are known to feed to satisfy their energy requirements, and if the diet does not contain sufficient energy levels, protein is used for energy rather than for growth [21]. Protein is the most expensive component in fish feeds and plays an important role in growth of fish (NRC, 1993) [22]. Previous studies demonstrated that providing properly balanced ratios of protein to non-protein energy in diets can spare dietary protein from energy metabolism and then increase its utilization for fish growth diets [2328].

In the current study, the Apparently Digestibility Coefficient of gross energy $\left(\mathrm{ADC}_{\mathrm{GE}}\right.$ ) range from $43.44 \%$ to $21.56 \%$ slightly higher than the Apparent Digestibility Coeffiencint $\left(\mathrm{ADC}_{\mathrm{CP}}\right)$ range for crude protein (31.45\%-24.15\%). An inadequate dietary protein dietary protein to energy ratio may result in lower growth as well as low protein and energy utilization in fish [28]. In diets with low protein to energy ratio, the use of dietary protein for growth and maintenance of body protein is maximized, while in diets with high protein to energy ratio, more protein is used for energy or stored as fat [28]. According to (Van der Meer et al., 1997), the protein sparing effect of energy occurs only if the 
Citation: Mzengereza K, Singini W, Msiska OV, Kapute F, Kang'ombe J, et al. (2016) Apparent Nutrient Digestibility of Plant Based Diets by Tilapia rendalli (Boulenger, 1896). J Aquac Res Development 7: 396. doi:10.4172/2155-9546.1000396

minimum protein requirements are met, including adequate amounts of amino acids. In addition, Apparently Digestibility Coefficient of gross energy $\left(\mathrm{ADC}_{\mathrm{GE}}\right)$ range from $43.44 \%$ to $21.56 \%$ slightly lower than the Apparent Digestibility Coeffiencint for crude fat $\left(\mathrm{ADC}_{\mathrm{F}}\right)$ range for crude protein (67.78\%-54.29\%). Providing adequate energy from dietary lipid can minimize the use of protein as an energy source [29]. Therefore, the presented study infers the protein sparing effect of plant diets as evidenced from the digestibility coefficients.

From the foregoing discussion, it can also be suggested that the digestibility coefficients from almost all diets analysed in the present study were lower than those reported in other studies on Tilapia due to poor utilization of the diets owing to among several reasons, presence of anti-nutritional the that impeded feed intake and subsequently digestion due to off flavors and toxicity nature although not investigated in the present study. These results agree favorably with Mbahinzireki et al. [14] who reported in his investigation of Cottonseed-meal (CSM) as a major source of protein for Tilapia (Oreochromis species). Results indicated presence of up to $0.11 \%$ to $0.44 \%$ gossypol and that was identified as a major limiting factor for acceptance of the CSM diets in tilapia farming.

\section{Conclusion}

The potential of feedstuffs such as leaf meal in fish diets can be evaluated on the basis of its proximate chemical composition, comprising the moisture content, crude protein, crude fiber, crude lipid, total ash and nitrogen-free extract. Results of the present study show that the crude protein content of Cocoyam, Cassava leaf and Black jack were higher than all ingredients analyzed. Digestibility coefficients indicate diets exclusively formulated from plant sources tested on Tilapia rendalli that have a low digestibility potential and subsequently less nutrient available for growth and energy. Therefore, knowledge of the digestibility of protein helps the farmer to deduce whether or not feed is meeting the targeted requirements of fish.

\section{Recommendation}

Based on proximate composition of the ingredients and digestibility coefficients of different diets fed to Tilapia rendalli, the study suggests inclusion of plant feedstuffs in Tilapia diets in order to minimize the cost of fish production among small scale fish farmers. The plant feedstuffs must however, be rid of anti-nutrition factors which negate growth of fish. To this end, application of heat through boiling, drying or roasting could be some of the methods that need to be advocated to rural fish farmers across the country to be performed before using the ingredients. There is also need for further research to evaluate among others, the amino acid profile, and anti- nutritional factors of the plant feedstuffs and as well as the diets as these have a profound effect on performance fish.

\section{References}

1. Allan GL, Parkinson S, Booth MA, Stone DAJ, Rowland SJ, et al. (2000) Replacement of fishmeal in diets for Australian silver perch, Bidyanus bidyanus. I. Digestibility of alternative ingredients. Aquaculture 186: 293-310.

2. Zhou QC, Tan BP, Mai KS, Liu YJ (2004) Apparent digestibility of selected feed ingredients for juvenile cobia (Rachycentron canadum). Aquaculture 241: 441-451.

3. Francis G, Makkar HPS, Becker K (2001) Antinutritional factors present in plantderived alternate fish feed ingredients and their effects in fish. Aquaculture 199: 197-227.

4. Portz L, Cyrino JEP (2004) Digestibility of nutrients and amino acids of different protein sources in practical diets by largemouth bass Micropterus salmoides (Lacepe'de, 1802). Aquaculture research 35: 312-320.
5. Adewolu MA (2008) Potentials of Sweet Potato (Ipomoea batatas) Leaf Meal as Dietary Ingredient for Tilapia zilli fingerlings. Pakistan Journal of Nutrition 7: 444-449.

6. Bureau DP, Harris AM, Cho CY (1999) Apparent digestibility of rendered animal protein ingredients for rainbow trout (Oncorhynchus mykiss). Aquaculture 180: 345-358.

7. AOAC (2003) Official Methods of Analysis. Washington, DC, USA.

8. Duncan DB (1955) Multiple range and multiple F-tests. Biometrics 11: 1-42.

9. Cho CY (1990) Fish nutrition, feeds, and feeding: with special emphasis on salmonid aquaculture. Food Rev. Int. 63: 333-357.

10. Altan O (2002) Investigations on appearent digestibility of nutrients in sea bass (Dicentrarchus labrax L., 1758).

11. Koprucu K, Ozdemir Y (2005) Apparent digestibility of selected feed ingredients for Nile Tilapia (Oreochromis niloticus). Aquaculture 250: 308-316.

12. Maina JG, Beames RM, Higgs D, Mbugua PN, Iwama G, etal. (2002) Digestibility and value of same feed ingredients fed to tilapia Oreochromis niloticus (L). Aquaculture Research 33: 853-862.

13. Fontainhas-Fernandes A, Gomes E, Reis-Henriques MA, Coimbra J (1999) Replacement of fish meal by plant proteins in the diet of Nile tilapia: digestibility and growth performance. Aquaculture. Int. 7: 57-67.

14. Mbahinzireki GB, Dabrowski K, Lee KJ, El-Saidy D (2001) Growth, feed utilization, and body composition of tilapia (Oreochromis spp.) fed with cottonseed meal. Aquaculture Nutrition 7: 189-200.

15. Hanley $F$ (1987) The digestibility of foodstuffs and the effects of feeding selectivity on digestibility determinations in tilapia, Oreochromis niloticus (L.). Aquaculture 66: 163-179.

16. Guimaraes IG, Pezzato LE, Barros MM (2008) Amino acid availability and protein digestibility of several protein sources for Nile tilapia, Oreochromis niloticus. Aquaculture. Nutrition. 14: 396-404.

17. Ogunji JO (2004) Alternative protein sources in diets for farmed tilapia. Nutrition Abstracts and Reviews 74: 23-32.

18. Stone DAJ (2003) Dietary carbohydrate utilization by fish. Rev. Fisheries Science 11: 337-369.

19. Eusebio PS, Coloso RM, Mamauag RE (2004) Apparent digestibility of selected ingredients in diets for juvenile grouper, Epinephelus coioides (Hamilton). Aquaculture Res earch 35: 1261-1269.

20. Altan Ö, Korkut AY (2011) Appearent Digestibility of Plant Protein Based Diets by European Sea Bass (Dicentrarchus labrax L., 1758). Turkish Journal of Fisheries and Aquatic Science 11: 87-92.

21. Cowey CB, Sargent JR (1979) Nutrition. In: Hoar WS, Randall DJ, Brett JR (eds). Fish Physiology Academic Press, London.

22. NRC National Research Council (1993) Nutrient requirements of warm wate fishes and shellfishes. National Academy Press, Washington, DC.

23. Nankervis L, Matthews SJ, Appleford P (2000) Effect of dietary non-protein energy source on growth, nutrient retention and circulating insulin-like growth factor I and triiodothyronine levels in juvenile barramundi, Lates calcarifer Aquaculture 191: 323-335.

24. Morais S, Bell JG, Robertson DA, Roy WJ, Morris PC (2001) Protein/lipid ratios in extruded diets for Atlantic cod (Gadus morhua L.): Effects on growth, feed utilization, muscle composition and liver histology. Aquaculture. 203: 101-119.

25. Wang Y, Guo JL, Li K et al. (2006) Effects of dietary protein and energy levels on growth, feed utilization and body composition of cuneate drum (Nibea miichthioides). Aquaculture 252: 421-428.

26. Schulz C, Huber M, Ofunji J et al. (2008) Effects of varying dietary protein to lipid ratios on growth performance and body composition of juvenile pike perch (Sander lucioperca). Aquaculture Nutrition 14: 166-173.

27. Ahmadr MH (2008) Response of African Catfish, Clarias gariepinus, to different dietary protein and lipid levels in practical diets. Journal of World Aquaculture Society 39: 541-548. 
Citation: Mzengereza K, Singini W, Msiska OV, Kapute F, Kang'ombe J, et al. (2016) Apparent Nutrient Digestibility of Plant Based Diets by Tilapia rendalli (Boulenger, 1896). J Aquac Res Development 7: 396. doi:10.4172/2155-9546.1000396

Page 6 of 6

28. Ali A, Al-Ogally SM, Al-Asgah NA, Gddard JS, Ahmed SI (2008) Effect of feeding different protein to energy $(\mathrm{P} / \mathrm{E})$ ratios on the growth performance and body composition of Oreochromis niloticus fingerlings. Journal of Applied Ichthyology 24: 31-37.
29. Takeuchi T, Shiina $Y$, Watanabe T, Sekiya S, Imaizumi K (1992) Suitable protein and lipid levels indiet for fingerlings of yellow tail. Nippon Suisan Gakkaishi 58: 1333-1339. 